\title{
The Evolution OF 'MALAY' LABOUR ACTIVISM, 1870-1947: protest among pearling crews in Dutch East Indies-Australian waters
}

\author{
Transforming Cultures eJournal, \\ Vol. 4 No 2 November 2009 \\ http://epress.lib.uts.edu.au/journals/TfC
}

\section{Julia Martínez1}

\begin{abstract}
The history of Indonesian labour activism as seen from an Australian perspective is best known in the context of World War Two when the presence of Asian seamen in Australia sparked a flourish of internationalism and anticolonial protest under the umbrella organization of the Seamen's Union of Australia. But the story of Malay maritime worker protest has a deeper history, reaching back to the early years of the pearl-shelling and trepang industries when Malay workers from the Dutch East Indies were brought to work off the northern Australian coast. Before the advent of a seamen's union, these workers faced harsh working conditions and had little recourse to legal forms of protest. Their refusal to accept poor conditions was met with reprisals which included physical punishment, gaol sentences and detention on board ships without shore leave. There is evidence that in the late nineteenth century the most common form of protest was mutiny, with Malay crews seizing vessels and sailing to the Dutch East Indies. By the twentieth century there was more scope for negotiation, with increasing support from Australian unions and improved government regulation. The milder forms of more recent protests and the willingness of Indonesians to take their cue from Australian unionists has somewhat obscured the nature of early Malay protest. This paper takes a longer view of worker activism in order to highlight the deep roots of maritime protest in the Indian Ocean region.
\end{abstract}

[Malays, seamen, activism]

\footnotetext{
1 Julia Martínez is a Senior Lecturer in Asian and Australian history and a researcher in the Centre for Asia Pacific Social Transformation Studies at the University of Wollongong, working on themes of colonialism, race and labour. E-mail: juliam@uow.edu.au
} 


\section{Introduction}

Malay crews from the Dutch East Indies provided a steady supply of labour for the dangerous but lucrative pearl-shelling industry in northern Australia from the 1870s to the 1950s. Despite changes in diving technology in the intervening years, the contracts of indenture that determined the working conditions of the divers and crew varied little, offering us the possibility of examining this maritime working culture over a relatively long period.

The pearl-shelling industry in the Malay Archipelago began as a local indigenous trade, with fisheries stretching from the Sulu Sea in the north to the Arafura Sea in the south. Pearl-shelling developed alongside the trepang trade in the nineteenth-century into a large, well-organised industry with fleets that carried over one thousand men. Dominated by crews from the vicinity of Makassar in the Celebes, including the Bugis and the maritime "sea-nomads" the Bajau², these maritime industries had their roots in the pre-colonial era, owing more to Malay and Chinese initiatives than to Dutch or other European influence. It is within these terms that the social hierarchy that underpinned a "Malay" understanding of labour relations needs to be understood.

In the case of north Australia, when the pearl-shell industry began in earnest in the 1870 s it was viewed as a colonial industry relying on non-European labour in the way of most Southeast Asian colonial ventures. The justification for the unashamedly poor working conditions of the Malay workers was based on colonial notions of racial hierarchy. In this schema Malays were ranked somewhat higher than Australian Aboriginal peoples but well below Europeans. When Japanese were later introduced as labour they were also valued above Malays. This colonial system lasted well beyond the advent of the Australian nation in 1900. In the final years of the industry, both master pearlers and the government alike were struggling to come to terms with the reality of a decolonising Indonesia and a new era of worker organization.

2 The term Badju Orang Laut which is used in nineteenth century sources may be confusing the Samalspeaking Bajau with a linguistically distinct Orang Laut people. See Clifford Sather (1997) The Bajau Laut: Adaptation, history, and fate in a maritime fishing society of south-eastern Sabah, New York: Oxford University Press. 
The transition from colonial to postcolonial was marked in the 1920s and 1930s by increasing evidence that workers from the Dutch East Indies were seeking and gaining support from Australian trade unionists in a bid to improve their working lives. These actions were seen as a direct attack on the colonial system of indenture and indeed on the colonial project itself. During this period is not surprising to find workers in a seafaring industry displaying a sense of worker solidarity and internationalism. The influences of western-derived communist politics were clear in the lead up to the Indonesian Revolution of 1945-1949. The period of decolonisation led to a new era of Australian-Indonesian labour cooperation. ${ }^{3}$ But even in this period of increasing internationalism, there is also evidence of an even stronger commitment to a sense of "Malay" labour community, as demonstrated in the 1947 establishment in Broome of a trade union organization called the Indonesia-Malaya Association. ${ }^{4}$

In this study, I aim to trace labour activism from the late nineteenth-century from the perspective of the pearl-shell workers themselves, albeit acknowledging the limitations of European-based sources. In order to avoid the Eurocentric assumption that worker protest was largely inspired by western models and influence, this account postulates a "Malay" form of maritime worker culture. During the nineteenth-century, in the Dutch East Indies there was already a well-established and sophisticated culture of maritime organization. How individual Malay crew members responded to their experience of the Australian industry should be seen in the context of their expectations based what might be loosely described as the Malay or Makassan maritime model. If we are to take seriously the study of transnational influences across the seas, then the flow of ideas must be seen to be circular like the ocean currents.

\section{Ethnic Diversity Among "Malay" Workers}

Henry Taunton, who spent time in the Western Australian pearling industry in the late nineteenth century, described the process of recruiting Koepanger crews, noting that first the captains had to sail to Kupang in Timor to pay security of $£ 20$ per head to the

\footnotetext{
3 Heather Goodall discusses the limitations of this cooperation in (2008) "Port Politics: Indian Seamen, Australian Unions and Indonesian Independence, 1945-47”, Labour History, 94: 64.

4 Adrian Cunningham (1992) "On Borrowed Time: The Australian Pearlshelling Industry, Asian Indentured Labour and the White Australia Policy, 1946-1962”, Master of Letters thesis, Australian National University: 46-47.
} 
Dutch government and then sail to one of the islands of Solor, Adonare or Alloo, where the captain "would have to bleed freely to the local rajah or chief before he would allow any of his people to engage as divers". As an employer, Tauton complained that unlike Aboriginal workers, who were paid only in food and tobacco, the Malays expected wages paid in rupees and food "of their own kind". 5

This idea of sailing to various islands in search of labour suggests that the terms Malay and Koepanger were used very loosely to refer to what was in reality an ethnically diverse group. The island of Solor, located to the north of Kupang and east of Flores, was described by J. H. Moor in the early nineteenth-century as having a maritime population whom he described as Badju Orang Laut. They were said to acknowledge the Dutch authority of Kupang. He wrote that they "are obliged to provide prows to transport the natives of Rotti and Savu to Timor, when their assistance is required". 6 The Solorese divers that Tauton refers to might therefore be Bajau, but if the Bajau themselves were involved in recruiting labour from the islands of Roti or Savu then Tauton's Koepanger crews may have been from these islands.

In this period crew-members were often referred to as Macassar men, but again in Makassar there were diverse ethnic groups, including Bugis, Makassarese and Malays. The assumption is that they were, in fact, Makassarese. Crews were also brought to Australia from Singapore and these men came from both Malaya (Straits Settlements) and the Dutch East Indies, having already travelled by sea to Singapore in search of work. In later years Australians recruited workers not only from Kupang in Timor but also from the Moluccas (Maluku); from Ambon and from the port of Dobo in the Aru Islands, thus adding further to the potential diversity of the workforce.

In Dutch East Indies records, the term "Malay" was used more specifically to refer to non-indigenous people who were descended from migrants from Malaya, such as those

\footnotetext{
5 Henry Taunton (1903) Australind: Wanderings in Western Australia and the Malay East, London: Edward Arnold: 211.

6 J. H. Moor $(1837,1968)$ Notices of the Indian Archipelago and Adjacent Countries, London: Frank Cass \& Co: $10 \mathrm{a}$.
} 
from the Malayo-Muslim polity of Melaka. ${ }^{7}$ In Australia, such distinctions were rarely made, with the term being more of a racial category and a broader regional marker that subsumed both those of Malay heritage and sometimes those indigenous to the various islands of Indonesia. With such a diversity of ethnic groups it becomes difficult then to talk about a "traditional" Malay sense of labour culture in the context of the pearlshelling industry. On the other hand, the maritime industries of the Malay archipelago had over time developed some sense of a multi-ethnic seafaring "community". One important common factor which united these workers was the use of the Malay trade language, which later became the national language of Indonesia and Malaysia. Anthony Milner's description of cultural Malayness offers a way of imagining the Malayness of the seafarers. He talks about Malayness as being primarily cultural, whereby "customs, language and attire" were taken up by the diverse peoples of the archipelago. His study of Malay texts also suggests that "aboriginal" peoples who became Malay could later revert to their traditional identification, as they put aside Malay customs. ${ }^{8}$

In Campbell Macknight's study of the north Australian trepang industry, he also points to the ethnic diversity of fishing crews. He cites Earl's description of the Macassar trade in 1842, in which Earl argues that "Macassars" were "even more skilful navigators than the Bughis" and that, while the Bugis rivalled the Macassars in all branches of trade, the Macassars still brought in more trepang from their activities in the north Australian fishery. ${ }^{9}$ The Makassan-Bugis rivalry is mentioned by British navigator Matthew Flinders in his description of an encounter with a Malay trepanging fleet off the north coast of Australia in 1803. His Malay contact, Pobasso, remarked that at least part of the fleet belonged to the "Rajah of Boni", Bone being Bugis territory. ${ }^{10}$

\footnotetext{
7 Heather Sutherland (2001) “The Makassar Malays: Adaptation and Identity, c. 1660-1790", Journal of Southeast Asian Studies 32(3): 398.

8 Anthony Milner (1994) The Invention of Politics in Colonial Malaya, Cambridge: Cambridge University Press: 102.

9 Cited in C.C. Macknight (1976) The Voyage to Marege, Macassan trepangers in northern Australia, Melbourne: Melbourne University Press: 15.

10 Macknight (1976: 17).
} 


\section{Slavery and Working Life under the 'Malay' System}

To trace the origins of the pearling industry we need to view the broader region, including the main pearling centres of the Sulu Sea situated to the north of the Celebes and south of the Philippines. James Warren's study, The Sulu Zone, 1768-1898, states that the task of collecting trepang and diving for pearls fell to "slaves, and the "sea people' or Samal Bajau Laut". He uses the term Samal Bajau Laut "to identify the maritime nomadic boat-dwellers of Sulu, northeast Borneo, and Celebes". ${ }^{11} \mathrm{He}$ argues that Bajau can be distinguished from slaves by their "ability to offer their allegiance and services to other political contenders in the face of unreasonable authority". ${ }^{2}$ Bajau are often termed "sea-nomads" and indeed they did represent a maritime diaspora in the Malay Archipelago. The collection of pearls, Warren writes, "demanded the exceptional diving skills of boat-dwellers and trained slaves". ${ }^{13}$ These divers could free-dive to a depth of 15 fathoms, with a few able to dive to 20 fathoms. Experienced divers could procure forty to one hundred shells a day in clear water. Despite this emphasis on slavery, we should not assume that the role of pearl divers was without prestige or reward. In the early period, a slave diver was entitled to his freedom (merdeheka in Malay) in return for finding a very large pearl, and all pearls under a penny weight were rightfully the property of the divers. ${ }^{14}$

In the nineteenth-century, when pearl-shell became more profitable than pearls, the industry expanded in size. It was the slave raiders of the Balangingi Samal who "annually brought several thousand captive people to Sulu to be trained to work alongside the Samal Bajau Laut in the tripang and mother of pearl fisheries". ${ }^{15}$ As an indication of the value of a slave, in the 1850s a prahu fishing vessel could be purchased for six to eight slaves. ${ }^{16}$ While Warren's observations relate to the Sulu region, we should not assume that Sulu-based slavery was geographically separate from

\footnotetext{
11 James Warren (1981) The Sulu Zone, 1768-1898, Dynamics of External Trade, Slavery, and Ethnicity in the Transformation of a Southeast Asian Maritime State, Singapore: Singapore University Press: 67.
}

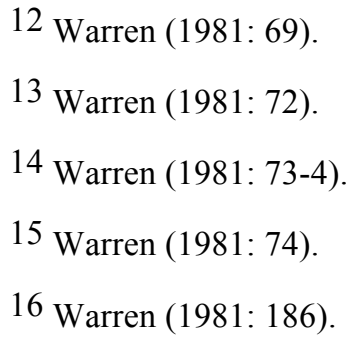


the north Australian or Dutch East Indies industry. In 1839, one of the prau leaving Port Essington in north Australia was captured by pirates from the Philippines and the crew taken as slaves to Mindanao. ${ }^{17}$

Slavery was also a part of the Makassan fleet that went to north Australia. Macknight discusses the conditions for trepanging crews, taking as his source a contract from the late nineteenth century. He suggests that some crew were either slaves or indentured, because in the terms of the contract it provided for payment to be made to a third party, who was entitled to the profit in the event that the crew member died. There has been no research in the Australian literature to suggest that Malay indentured workers in the Australian pearl-shelling industry might have been similarly bonded, but given that these two industries operated in the same period, on the same coast and recruited from much the same sources, it seems likely that there were more parallels than have previously been recognised.

In the Makassan contract there was also a provision dealing with misconduct by both crew and master. The contract stated that in the event of deception by a crew-member, either by decamping with his advance before the voyage or obtaining a second advance from another master, the debt of the original advance is doubled. The contract also allowed for the crew to be released from an untrustworthy master. ${ }^{18}$ Examining the Makassan system, Macknight argues that is would be "a misunderstanding to regard the ordinary crew members as oppressed, exploited and ground down by a perpetually increasing burden of debt". ${ }^{19}$ He calculates that an average return in the 1880 s was about 100 guilders or $£ 8$ plus a basic food ration for nearly half the year. Because the crew took a percentage of the profits, Macknight concludes that this suggests a striking "interdependence between the various parties" given that "all benefit in fixed proportion from a successful voyage". ${ }^{20}$

\footnotetext{
17 Earl cited in Macknight (1976: 132).

18 Macknight (1976: 20-1).

19 Macknight (1976: 22-3).

20 Macknight (1976: 23).
} 


\section{Regulating Pearling on the North-West Australian Coast}

It was not co-incidental that the pearling masters of Western Australia chose to employ Malays on their pearling luggers. As with the Northern Territory, there were Malay seafarers operating on the Kimberley coast long before the British colonised the region. In 1803, Nicholas Baudin, sailing off the Kimberley coast, recorded a fleet of 24 praus from Macassar. The average crew size was 30 men which suggests that there were over 600 crew. ${ }^{21}$ Just as the Northern Territory was referred to by the Malay term Marege, the Kimberley coast also had a Malay name of Kayu Jawa. ${ }^{22}$ The Aboriginal Bardi people of the islands off the coast of the Dampierland Peninsula were said to have Malay heritage from early contact with Indonesian seafarers who came south on the monsoon winds. ${ }^{23}$

The colonial government of Western Australia was established in 1825 and it was not until 1883 that Broome, located on Roebuck Bay, or Nileribanjen in the language of the local Aboriginal Djuleun people, was proclaimed as a town. Prior to 1883 the port of Cossack, also on Roebuck Bay, was the primary pearling port. When the pearling industry was first established, the labour was supplied by Aboriginal men and women, initially mostly Bardi people, who were captured by "blackbirders" and sold to the pearling masters as skin divers. Thus, by coincidence or emulation, the Australian industry also relied on "slave" labour for its divers.

When the Australians turned to Malay labour, there is evidence that at least some of the Malay crews were also being held against their will by pearling masters. In 1873, some Malays working for Captain Cadell made a complaint to the Stipendiary Magistrate, E.H. Laurence, stating that there had been a breach in their agreement and that they were being detained in Western Australia beyond the lawful term of their contract and against their wishes. This prompted Laurence to request that when vessels arrived with Malays they should be obliged to register their agreements with some authorised

21 Macknight (1976: 27-9).

22 Macknight (1976: 33).

23 Hugh Edwards (1984) Port of Pearls, Broome's First 100 Years, Swanbourne: Hugh Edwards: 105; see also Malay connections to the Northern Territory, Regina Ganter with contributions from Julia Martinez \& Gary Lee (2006) Mixed Relations, Asian-Aboriginal Contact in North Australia, Crawley, University of Western Australian Press: 8-9. 
person. He noted that the Malays were "almost as helpless to enforce their agreements as the natives and are as liable to ill usage". ${ }^{24}$

The Western Australian government took action to regulate the conditions for Aboriginal workers after 1871 with various Pearl Shell Fishery Regulations which banned women divers, limited diving depths and insisted that Aboriginal divers were signed on in front of a magistrate and returned to their homes at the end of the season. This legislation prompted pearlers to employ even more Malay crews and in 1875 there were 989 Malays and 493 Aboriginal people employed on the 57 vessels licensed out of the port of Cossack on Roebourne Bay. Estimates including other ports suggest a total of 1800 Malays employed in Western Australia. Conditions for Malay workers remained poor and, when Lieutenant Suckling reported that year on the Malay workers, he found that out of 548 Malays who had signed on, 33 had died and many were sick. ${ }^{25}$

During this period the evidence suggests that the Malay crews brought to Western Australia from Singapore were anything but the experienced divers we might have expected. In 1872, a pearling master, Broadhurst, who imported over 140 Malays on the SS Xantho, received men who were described as having "not the slightest idea of either swimming or diving, being completely out of their element in the water". ${ }^{26}$ It was not surprising then that the death rate for workers was high.

Apparently the death rate was also high for workers from the Dutch East Indies. The Dutch authorities became concerned over the treatment of the men and introduced legislation that included a bond of 200 florins per diver to be forfeited by the pearling master if the Malay died or was not returned to his home-port within 13 months. Malay wages were also fixed at what the pearling masters regarded as unreasonable rates. In protest over these regulations, only 72 Malays were employed in $1883 .{ }^{27}$ By 1887 , the

\footnotetext{
24 J.H.M. Honniball (1975) "E.H. Laurence, Stipendiary Magistrate”, Early Days: Journal of the Royal Western Australian Historical Society, 7 (7): 23.

25 Edwards (1984: 46-7); Ronald Moore (1994) “The management of the Western Australian pearling industry, 1860 to the 1930s", Great Circle 16 (2): 127.

26 Cited in Mike McCarthy (1994) "Before Broome", Great Circle 16 (2): 84.

27 McCarthy (1994: 85).
} 
nature of the pearling industry was changing with the introduction of the copper helmet and full diving dress to replace skin-diving, which then led to the more dangerous practice of deep water diving. Aboriginal and Malay divers were used less and Japanese divers came to dominate the industry. ${ }^{28}$ Japanese divers had a reputation for being the best divers, being supposedly fearless and associated with the introduction of technical modifications into the industry. Because of their productivity, they were favoured by pearling masters, even when they demanded increased wages. ${ }^{29}$

\section{Malay Protest: Mutiny and Piracy}

In the 1870 s, with little supervision and regulation, the situation for the Malay workers was such that many were driven to take action against their employers. Captain George Roe, of the schooner Gift, lost his vessel when his crew mutinied and sailed away to the Dutch East Indies. The Gift had arrived from Koepang on 20th October 1872. On board were the Master, Christie, and the owners, Roe and Passey, and 37 Malay divers, 13 of whom were "Macassar men", who were engaged for collecting, shelling and curing of trepang. Apparently these men were experienced, being described as "useful as sailors and fair divers". ${ }^{30}$ Three weeks out from Koepang, they called in at the Lacepede Islands.

Roe later gave testimony that the men were "very obedient, and conducted themselves entirely to our satisfaction". The trouble came after four days of shelling. Roe had spoken to the serang whose job it was to supervise the men. Roe stated that he "appeared quite satisfied, and asked me what I thought of his men. I replied that I was well pleased with them; he ... appeared pleased that he and they were giving satisfaction". ${ }^{31}$ Despite these assurances on both sides, that night Passey was attacked and a battle ensued between the crew and the white masters, leaving Christie and six Malays dead and Passey lame. ${ }^{32}$

\footnotetext{
28 Edwards (1984: 47); Moore (1994: 129-30).

29 Regina Ganter (1994) The Pearl-Shellers of Torres Strait, Melbourne: Melbourne University Press: 99 \& 109 .

30 "Mutiny and Murder on Board the Schooner Gift", The Brisbane Courier, 18 February 1873: 2.

31 Ibid: 2.

32 Ibid. 2.
} 
Passey gave evidence that it was the Macassar men who had attacked him without provocation and that it was the serang who had tried to kill him. According to Balachandran, writing on Indian seamen, in colonial discourses the serang supposedly held "a traditional position of authority over a crew drawn mainly from his village and bound to him by village-level ties of fealty and subordination". But, he argues that colonial officials "often misconstrued the serang as an intermediary" between the captain and the crew. ${ }^{33}$ In the case of the Gift, Roe apparently trusted the serang and was satisfied that the serang was in his service, whereas during the mutiny the serang appears to be a leader of the Macassans. The Argus correspondent wondered at pearlers trusting themselves amongst "men who have a world-wide reputation for treachery and ferocity". ${ }^{34}$ Roe claimed that the other Malays did not help the Macassar men, and indeed when the men were captured in the Moluccas, it was reported that there had been "a row among the pirates, in which the Macassar men got the best of the scrimmage and threw their Malay brothers in guilt overboard". ${ }^{35}$ It would appear then, that it was the experienced Macassar men who undertook to steal the vessel. Roe stated that he did nothing to provoke the men, but perhaps he misread his conversation with the serang. If we set aside the notion that the men acted only out of "treachery" then we might consider instead the possibility of some misunderstanding over the handling of the pearl-shell that led the Macassar men to assume that Roe was in breach of contract.

This was not an isolated incident. In 1899, the Malay crew of the brig Ethel mutinied and killed Captain Riddell along with his son and the first mate. They sailed to Kupang where they scuttled the vessel offshore and swam ashore claiming to be victims of a storm. They were turned in to the Dutch authorities by the Chinese cook, John Chi, and were sent back to Australia to Fremantle where they were convicted of murder and hanged. ${ }^{36}$ A.C.V. Bligh, who arrived in Broome in the year 1900, commented on the Riddell case stating:

33 Gopalan Balachandran (2008) "Cultures of Protest in Transnational Contexts: Indian Seamen Abroad, 1886-1945”, Transforming Cultures eJournal 3 (2): 53.

34 "Western Australia", The Argus, 21 January 1873: 15.

35 “The North-West Coast", The Argus, 21 May 1873: 7.

36 Edwards (1984: 67-8); J.K. Loney (1994) Wrecks on the Western Australian coast: and Northern Territory, Perth: Lonestone Press. 
These mutinies had lately occurred so often, that the fleet owners decided to form an alliance to combat these plots and to raise funds for their mutual protection. ...It was most important to find Captain Rudel's (sic) boat and punish his crew, because too many of these eastern crews had lately disappeared and become well-to-do settlers on one of the islands, so tempting other crews to follow in their footsteps. In many cases, fleet owners had taken the law into their own hands, when catching up with an absconding crew. ... From that time on we never had more than three men from the same country on a boat and this always worked well, especially when there was a fight. ${ }^{37}$

Bligh was concerned that the pearling "crews had lost all fear of punishment in being sentenced to gaol, because there they could rest and eat well" and he commented on the captain needing the "right to enforce discipline" in the event of the "crew refusing duty". 38

Another incident in which Malay sailors took action occurred in 1903 when five Malays joined together to steal a pearling lugger. In this case there is no suggestion that the crew were "Macassar men". Kassim Bin Amid had signed on in Singapore through a coolie broker. He was born in Tanjung Pinang on the island of Bintan, Riau Islands, in the Dutch East Indies. ${ }^{39} \mathrm{He}$ signed on with a three-year contract of indenture to work as crew on the pearling lugger Blue Bell, owned by Captain Shaw. His first disagreement with Shaw allegedly came when he objected to having to work on Sunday and was beaten by the Captain. Later, when the vessel put into Broome for supplies, Kassim ran away and hid in Chinatown. Shaw had Kassim arrested and forcibly returned to the Blue Bell. 40

Later in May 1903, when the Blue Bell moored in Broome for the last time before setting out for sea for an extended period, Kassim and his shipmate Ahmat Bin Deen were told that they were to remain onboard as watchmen. They were unhappy at being denied the right to go into town. That evening they called out to two other luggers

\footnotetext{
37 A.C.V.Bligh (1958) The Golden Quest, The roaring days of West Australian gold rushes and life in the pearling industry, Carlisle: Hesperian Press: 194-5.

38 Bligh (1958: 157).

39 Bintan is also home to a sea nomad people, the Orang Suku Laut.

40 Rod Dickson (2002) The Price of a Pearl, Carlisle W.A.: Hesperian Press: 72.
} 
moored nearby, the Blanche and the Flora and invited Raji Bin Hassan, Sarip Bin Tokaya and Samsudin Bin Ali to come aboard. That night they decided to steal the vessel and sail it to Singapore. ${ }^{41}$ They set off towards the Dutch East Indies, but after damaging the hull on a reef the crew went ashore at Labuan Hadji in Lombok. Kassim enquired at the Harbour Master's office for a new certificate of registry, claiming to have lost the ship's papers. When that request was denied they sailed to Sumbawa and there sold the vessel to an Arab merchant for 450 guilders, selling a vessel worth over $£ 500$ for approximately $£ 37 .{ }^{42}$ Taking a coastal vessel to Singapore, the men stopped over at Labuan Hadji on the way. They came to the attention of the Master's Attendant who notified the police. They were captured and extradited to Broome where they were sentenced to four years hard labour. ${ }^{43}$

These men came from various locations in the Malay Archipelago, three of them being originally residents of the Dutch East Indies. In joining together to steal the lugger they were apparently most concerned to escape from their contracts of indenture. The money they hoped to gain from the sale of the lugger was a relatively small amount when divided between five men. The restrictions of indenture were common in Southeast Asia at this time, but unlike most workers who worked on plantations, these men had the option of taking to the high seas in order to escape their term of servitude. It is a testimony to the unexpectedly close connections of the Dutch and British colonial authorities that such escapees were able to be caught and returned to "hard labour".

It is possible for these 'Malay' crews to be labelled as criminals and pirates, whose actions were justly punished. In The Many-Headed Hydra, Peter Linebaugh and Marcus Rediker invite us to consider instead the actions of sailors, pirates and slaves as being revolutionary in spirit. Likewise, we might consider these men who protested against the injustice of indenture as pre-empting later, more formal protests by Australian unionists and international humanitarians. For Linebaugh and Rediker the "motley crews" who engaged in rebellion and mutiny should be regarded as the sea-going

\footnotetext{
41 Dickson (2002: 74-6).

42 Dickson (2002: 80).

43 Dickson (2002: 103).
} 
equivalent of the urban mob or the revolutionary crowd. ${ }^{44}$ Just as the history of the Atlantic Ocean was potentially enriched by this new approach, so too a history of the Indian Ocean has its own subversive or subaltern histories. In a critique of Linebaugh and Rediker's view, Balachandran, who writes just such subaltern histories of the Indian Ocean, cautions against invoking "an almost mystical and historically stable realm of maritime working class militancy". ${ }^{45}$ In his study of Indian seamen, he suggests a more pragmatic reading in which protest was undertaken as the opportunity presented itself. $\mathrm{He}$ argues that while mutinies were feasible in the era of sailing vessels, they were "unsustainable in the more regulated late-19th century steam environment". ${ }^{46}$ In the case of the pearling luggers, however, much like the early sailing vessels, the balance of power lay firmly with the crew.

\section{Regulation and Discipline under the White Australia Policy}

Malays who signed up to work in the pearl-shell industry after 1912 were required to abide by the pearling agreement as set out in the Western Australia Pearling Act, 1912. The penal provisions of this Act specified penalties for breach of agreement, desertion and insubordination. Desertion, for example, could be punished with three months imprisonment or the forfeiture of all accrued wages and "lay", ${ }^{47}$

In 1914 the industry in Western Australia was dominated by Japanese, with 1,115 employed, but there were also 585 Malays and 247 Koepangers employed. ${ }^{48}$ Authorities were concerned over the reliance on Japanese and were encouraging the continued use of Malay labour. A labour trader, Mr L. I. Goldstein, arrived in Broome with 12 Malay divers from the vicinity of Makassar. Goldstein reported that in his trip through "the pearling centres in the Dutch Indies" he had found that labour was "extremely plentiful"

\footnotetext{
44 Peter Linebaugh \& Marcus Rediker (2000) The Many-Headed Hydra, Sailors, Slaves, Commoners, and the Hidden History of the Revolutionary Atlantic, London: Verso: 213.

45 Balachandran (2008: 71).

46 Balachandran (2008: 71).

47 Cunningham (1992: 18).

48 “Pearling Industry”, Nor'West Echo, 11 July 1914.
} 
and stated that he was of the "opinion that all the men required to work the W.A. pearling industry can be obtained from these islands". 49

The pearl-shell industry continued to employ Asian workers as an exception to the White Australia policy which otherwise was opposed to Asian labour. In 1916, the results of a Royal Commission into the pearl-shell industry concluded that the industry would continue to be granted this exemption. ${ }^{50}$ The 1916 report argued that the pearlshell industry was not suitable for white divers, stating:

The life is not a desirable one, and the risks are great, as proved by the abnormal death rate amongst divers and try divers. The work is arduous, the hours long, and the remuneration quite inadequate. Living space is cramped, the food wholly preserved of its different kinds, and the life incompatible with that a European worker is entitled to live. ${ }^{51}$

For the Australian government, the exemption was ultimately a pragmatic concession to the master pearlers who had threatened to move their luggers to the Dutch East Indies if they were denied access to Japanese divers. ${ }^{52}$

As a concession to the White Australia policy, registers were kept detailing the date of employment, the number and nationality of indents, deaths and causes, and prosecutions. These were ostensibly intended to monitor and protect the working conditions of the indents. The recording of prosecutions, however, was designed to reassure the prejudiced fears of the white community. At the first sign of "racial" conflict or "undisciplined" behaviour, the government could order the repatriation of the indents in question. ${ }^{53}$

\footnotetext{
49 “Pearling Industry Malay Divers”, Nor'West Echo, 4 April 1914.

50 Lorraine Philipps (1980) "Plenty More Little Brown Man! Pearlshelling and White Australia in Queensland 1901-1918" in E. L. Wheelwright \& K. Buckley (eds.) Essays in the Political Economy of Australian Capitalism, Vol. 4, Sydney: Australia and New Zealand Book Company: 73-5.
}

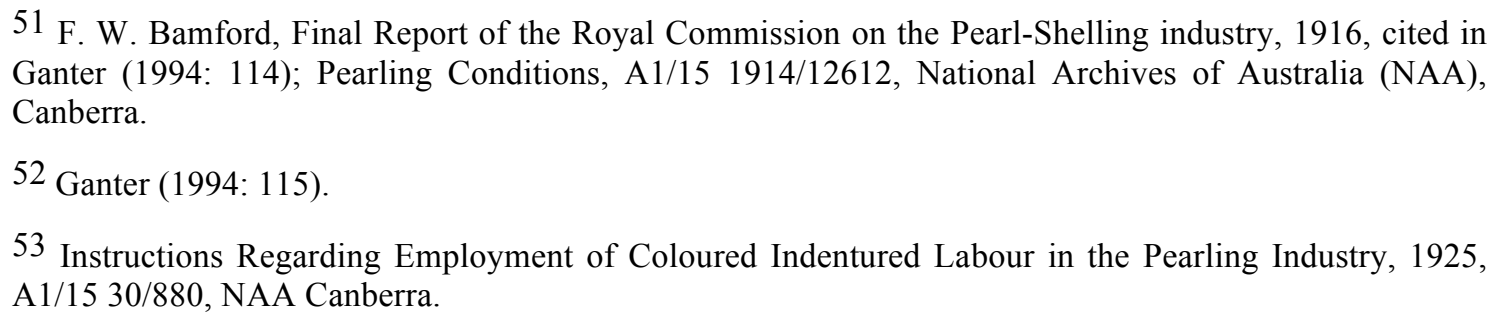


In one incident in 1916, we see the manner in which the law was used to suppress worker activism. When the schooner Muriel arrived at Broome with 28 men from Koepang, the men at first refused to sign pearling contracts that stipulated a wage of 25/- per month. In response, they were declared prohibited immigrants and put in gaol. When they subsequently agreed to sign the contracts they were released into the custody of their employers. ${ }^{54}$

\section{Protest and Internationalism: Malays join with Australian Unionists}

Of the pearling ports in northern Australia, Darwin had the most significant union movement, being the headquarters of the North Australian Workers' Union (NAWU). If we are to consider the interactions between Malay workers and Australian unionists, this site offers more evidence of interaction than Broome. Darwin had been a pearling port since 1884 , but it was only in the late 1920 s, after several pearling masters moved their fleets from Broome to Darwin, that it rose to prominence as a pearling centre. In 1927 the NAWU was formed, but its membership rules excluded Chinese, Japanese, Kanaka, Afghan and "any colored race", which effectively excluded Malays. ${ }^{55}$ Attempts to remove the "colour bar" on NAWU membership led to a split between Labor and Communist unionists. ${ }^{56}$ At the 1930 annual meeting, communist members proposed a new membership rule to allow "all bona-fide workers irrespective of color" into the NAWU, but their proposal was rejected ${ }^{57}$

There is very little evidence relating to Malay pearl-shell workers for the period between 1916 and the late 1920s, but this was most likely due to the relatively low levels of production during these years. In terms of this study of Malay protest, this is unfortunate because it was in the early 1920s that we see intense worker activism in the Dutch East Indies. The later years see a decline in organised strikes. John Ingleson

\footnotetext{
54 Crown Solicitor, Opinion, to Secretary, Attorney-General's Dept, 1 March 1916, “Koepang Pearling Indents" A1 1916/10463, NAA, Canberra.

55 NAWU, Constitution and General Rules, Rule 6, Mitchell Library, NSW.

56 Northern Standard, 30 August, 1 October, 8 October 1929.

57 Northern Standard, 2 September 1930.
} 
argues that following the 1923 railway strike new Dutch regulations gave the government the power to crush strikes. ${ }^{58}$

The need for union support was more important to Malays and Koepangers, who were usually employed as crew-members, than it was for the Japanese who were mostly employed as divers and divers' tenders. There was a clear hierarchy amongst the Asian workers and it was not until the late 1930s that Malays were again able to rise up to the rank of diver. This was a hierarchy based on the assumption that Japanese were inherently more skilled and more driven to succeed. In Broome, most Japanese divers had been operating under a system known as "dummying" in which a diver was effectively the captain of the lugger even though to satisfy the regulations the official owner of the lugger was a "white" master. 59 When divers transferred to Darwin, they were officially working for white Pearling Masters, but again they were able to demand high wages. In 1928, divers were paid $£ 100$ a ton for shell raised, on the condition that the diver paid for the expenses of the boat after it had been made ready at the beginning of the season. This arrangement made the diver the captain of his lugger with the control of a partner. In 1929, in order to entice more men from Broome, the Pearlers offered to pay divers $£ 130$ per ton for shell. ${ }^{60}$ With the Japanese gaining strength of numbers in Darwin in 1931, a Japanese Divers' Society and a Divers' Tenders' Society was formed. In 1932, when the divers went on strike, the Standard commented:

Some concern was felt that the industry may be imperilled but others in the know declared it was only the annual bluff put up by the divers, who were, of course, out to secure the best possible conditions for themselves. ${ }^{61}$

The Japanese workers were therefore well organised and in a position of considerable strength in terms of their bargaining power over pearling masters.

The Malay workers, by comparison were largely employed as unskilled workers who were more easily replaced. This meant that they were in a more vulnerable position and

\footnotetext{
58 John Ingleson (1986) In Search of Justice, Workers and Unions in Colonial Java, 1908-1926, Singapore: Oxford University Press: $242 \& 255$.

59 Sun, Sydney, 1 February 1929, A1/15 28/11303, NAA Canberra.

60 Kepert to Department of Home and Territories, 25 January 1929, A1/15 28/11303, NAA Canberra.

61 Northern Standard, 19 February 1932.
} 
in need of either government or union support if they were to avoid exploitation by the pearling masters. Unfortunately, they were also regarded as a potential threat by the NAWU officials, who were primarily concerned about white unemployment. In 1928, the NAWU officials lobbied for stricter supervision of indentured workers in relation to onshore work, concerned that Asian indents were being given jobs that might have gone to white Australian workers. Indentured crews were employed in unloading, weighing, sorting and packing shell. Over the next ten years, the NAWU noted every incident of illicit employment of indentured crew and accused the government of not taking steps to uphold the White Australia policy. ${ }^{62}$ In 1930, Robert Toupein, secretary of the NAWU, sent the Minister of Home Affairs a list of jobs which he argued should be reserved for white labour. He included chipping, shell-packing, box-making, loading and unloading shell, and cutting timber. He further suggested that such restrictions should be enforced by the "immediate deportation of the labourer" and a penalty upon the Master Pearler if the latter was the offender. ${ }^{63}$ While this comment regarding deportation suggests a very hard line against the workers themselves, in practice the NAWU was somewhat more supportive.

In 1929, two Koepangers, Mateas Lili and Martin Bela, indentured by Master Pearler Clark, were deported from Australia after refusing to work carrying mail and stores to the Cape Don lighthouse. ${ }^{64}$ They argued that they had signed on to engage in the pearling industry and not to carry cargo. They were prosecuted under Section 390 of the Navigation Act and sentenced to 28 days imprisonment. They were released on the recognisances of Don McKinnon, editor of the NAWU newspaper, the Northern Standard. Once released, the Koepangers were living in the camp of Mahoney, a communist member of the NAWU. Finally the two were declared "prohibited immigrants" under the Immigration Restriction Act and deported.

\footnotetext{
62 Memo, Sub-Collector of Customs, Darwin to Department of Home and Territories October 29, 1928, A1/15 30/880, NAA Canberra.

63 Toupein to Minister of Home Affairs, 11 January 1930, A1/15 30/880, NAA Canberra.

64 Customs and Excise Office, Darwin to Department of Home Affairs, 26 March 1929, A1/15 29/1132, NAA Canberra.
} 
In 1931, three Malays recruited from Singapore approached the union asking for help. They were to be repatriated back to Singapore but had not been paid for three months and were owed £9. The NAWU Secretary, Toupein, took the matter up with the Customs and Fisheries Office and then approached Ulrich, the manager for Gregory and Co. Negotiating commenced and finally Ulrich informed Toupein that he agreed to pay their wages of $£ 3$ per month. The money owed was for the period between the end of the season and the arrival of the next steamer. Even though a new season's crew had been signed on from March 1, they were forced to wait until April 24 for the steamer. ${ }^{65}$ In this instance, the NAWU supported the Malay crew-members as if they were union members. The only indication from the Northern Standard that these workers were not part of the Darwin community was the fact that the three workers remained unnamed in the lengthy newspaper report. Toupein's stance on the subject of "coloured" labour was equivocal. Even though he was concerned over their exploitation, he nevertheless continued to support white labour wherever possible. In this sense he was not influenced by the anti-racist strategies espoused by the communist unionists.

The NAWU increasingly portrayed itself as the benevolent protector of Malay indents in this fashion. In 1936, the new secretary of the NAWU, J.A. McDonald, wrote regarding shore work:

The men used are mostly Malays, and it may be said in passing, that they are used for shore work, very much against their will. When they join a pearling lugger, their wages are fixed at $25 /$ - per month, and they are given to understand that they have only to work on the boat. They are told that the Australian law does not allow them to work on shore, but they are soon disillusioned when the boat reaches Darwin. Under threats of being sent to Fanny Bay gaol, they are compelled to load the shell on to lorries, and unload it when they reach the sheds.

While McDonald continues to describe the indents as "sweated alien labour" he does acknowledge that they are doing their best to negotiate for better conditions in a difficult situation, stating that: "They know that they are being exploited and have no other way of seeking redress". 66

65 “Indentured Laborers Obtain their wages”, Northern Standard, 14 April 1931.

66 J.A. McDonald, "Indentured Labor in Darwin, White Australia Policy Flouted," Northern Standard, 24 January 1936. The ambivalent attitude of white unionists towards the continued use of "coloured" 
When considering the action of Malay crews in the 1930s, it appears that their preferred form of protest was negotiation rather than the open rebellion of the early period. It is worth noting, however, that the old forms of protest were by no means a thing of the past for seamen in the Dutch East Indies. In 1933, there was an infamous case of mutiny on the Royal Netherlands warship, the Seven Provinces, which had a mixed Dutch and Indonesian crew. The mutiny was in response to pay cuts and generally poor morale amongst the crew. According to historian Lawrence Stokes, an Indonesian nationalist led the mutineers, though the Chamber of the People's Council in Batavia claimed that the mutineers were "native and part-European". ${ }^{67}$ At the time, the Sydney Trades Hall supported the mutineers. ${ }^{68}$ When the crew were eventually captured, W. Wellman of the Australian Seamen's Union, went to London to assist in the defence of the 19 Javanese sailors who were to be sentenced for their part in the mutiny. ${ }^{69}$ The case made headlines in Australian newspapers so we can assume that the Darwin unionists were aware of the mutiny and this may have influenced their willingness to support Malay labour protests.

In 1938, 14 Malays from Dobo went to the NAWU office, complaining that their wages had been stopped for three days and that their rations had been cut. The union secretary, McDonald, interviewed their employer, Clark, who claimed that the rations were in accordance with the contract he had with the Dutch Comptroller at Dobo. ${ }^{70}$ McDonald reported the matter to the Chief Pearling Inspector, Nylander, who in turn wrote to Clark stating:

The Dutch crew from your vessels saw me ... There seemed to prevail a certain dissatisfaction amongst the men about rations at the camp. This would be a matter of settlement between you and the men ... As a matter of course I inspected the camp in the afternoon, everything was clean and tidy. ... The crew told me they had no salt, milk, tea (there was coffee) curry or sauce. Their maintenance is a matter for the employer, and perhaps you will

labor is discussed in Julia Martínez (1999) "Questioning 'White Australia': Unionism and 'Coloured' Labour, 1911-1937”, Labour History 76: 1-19.

67 Lawrence Stokes (1977) Review of J.C.H. Blom, De muiterij op de Zeven Provincien [The Mutiny on The Seven Provinces], American Historical Review 82 (2): 377; "Dutch Mutiny", The Argus, 21 February 1933: 7.

68 “Sydney Unions Support Mutineers”, The Argus, 10 February 1933: 7.

69 “Javanese mutineers”, The Argus, 17 November 1933: 10.

70 Note that Dobo had been the main pearling market in the Dutch East Indies since the 1800s. Mary Albertus Bain (1982) Full Fathom Five, Perth: Artlook Books: 13. 
look into this matter, as I naturally felt restrained to discuss this phase of your camp arrangements with your crew.71

The reprimand was effective and the crew wrote to the Northern Standard to express their appreciation of the union support:

We, the undersigned Dobo Malays, of the Dutch East Indies ... wish to show our appreciation to the N.A.W. Union, especially to Mr. J. A. McDonald, the Secretary, and thank him for the trouble he took in fighting on behalf of us concerning the deduction of wages, shortage of tucker, and accommodation. ${ }^{72}$

They were scathing in their criticism, writing: "Fancy the capitalist Government helping the slave labour industry! We do not think Hitler could do worse things in Germany than the way we are treated here". The letter was signed with six names. The men made use of an interpreter, W. Gonzales, who was most likely from the Philippines. ${ }^{73}$

Despite the emphasis on poor treatment, it appears that the Dutch colonial government believed the Australian system to be too lenient. In 1937, a complaint was received from Dobo indicating that the Dutch administration disapproved of the freedom allowed Dobo Malays in Darwin. It was suggested that the Australian government should take action to regulate the behaviour of indents and to prevent them from entering hotels. In February 1937, a correspondent from the port of Dobo complained:

The Dutch Government view with alarm and concern, the attitude, and the big ideas, some of the local natives (Indents) adopt when they return on completion of their term in Darwin. ${ }^{74}$

The correspondent noted that the Dutch at least knew how to "manage and administer their native population". Commenting on the difference between the Dutch and Australian systems, he argued that

71 K. Nylander to Manager, Territory Pearling Company, 10 December 1938, F1 1938/726, NAA Darwin.

72 Letter to the editor, “The N.A.W.U. Thanked”, Northern Standard, 23 December 1938.

73 The names listed are Hermanus, Chasim, Abde, Arnold, Alexsander and Simson, Letter to the editor, "The N.A.W.U. Thanked", Northern Standard, 23 December 1938.

74 “Aroe Island Notes”, Northern Standard, 26 February 1937. 
... it does not matter what position in life a white man holds - he is always a "Toean" and is respected as such, and it is to be hoped that those "Whitemen" of Darwin who mix and associate with the native indents, will try and uphold their prestige as a white man, and not forget that Australia is proud of her "White Australia". ${ }^{75}$

These comments are a reminder that the Dutch colonial government had increased its surveillance of these eastern islands since the 1870s. If the Malay fisheries had once operated with a degree of autonomy under the Rajas, by the 1930s there was a greater sense of Dutch control and an absolute disapproval of what were regarded as dangerous political developments.

\section{Developing a Sense of Maritime Labour Community}

Labour historians have taken considerable interest in the phenomenon of maritime labour activism, noting the powerful sense of labour community that seamen have displayed over time. One of the crucial arguments has always been to gauge the degree to which sailors were better able to relate to the principles of international solidarity as opposed to the more exclusive national-based solidarity of land labourers. It is striking in the case of indentured pearling crews that they appear to belong more to the sea than to any one land or island. Notions of home, family, community and land-based loyalties are difficult to sustain when you have left the family at a young age and spent the better part of your life on the high seas. Pearling crews spent nine months of the year at sea. Even so, there is evidence that Malay crews were able to sustain a sense of "Malay" identity, and even to use the sea as a meeting place. We know that the fleets sailed together and that the fleet represented a kind of temporary community. Bligh captures this sense well:

Whilst out on the pearling grounds, many luggers and schooners would be working in groups, within easy rowing distance of each other. The schooners, carrying large supplies of stores, firewood, water and duty-free spirits, acted as mother ships to large groups of luggers. ...It was customary for some hundreds of luggers to foregather for inter-lugger visits, and pearlers would visit their special friends, and crews would have a gettogether with their fellow countrymen. At times, nearly a thousand men would be engaged on such visits. ${ }^{76}$

\footnotetext{
75 Ibid.

76 Bligh (1958: 183).
} 
If to be transnational is to live across two nations, then these seamen were not transnational. They worked between nations, between colonies. Like transnationals they moved back and forth between their homeland and the host country, but this mobility was not from choice, nor from any sense of belonging, but the result of Dutch regulations stipulating that workers from the Netherlands East Indies were to be returned to their home-port at the end of their two or three-year contract. Nor was the experience of visiting home necessarily positive. The voyage itself was difficult. A 1923 report from the British Consul in Batavia to the Netherlands East Indies governor complained that the schooners carrying indentured workers between Kupang and Western Australia were loaded with two passengers per ton - double the number recommended for Atlantic slave ships. Given that we know that workers were recruited in ports such as Singapore and Kupang but were actually born in various other locations, we cannot even be sure that indents who were returned to these ports would have ever made it home before signing on again to a new contract.

In thinking about the development of a maritime form of labour activism, I would argue that the influences on individual "Malay" workers were very much a product of the collective maritime experience. Undoubtedly the Dutch authorities believed that workers' growing political awareness was the product of their interaction with white unionists in Australia. From the Dobo Malay comments about Hitler we can speculate that crews had access to newspapers and took an interest in international affairs. They would have similarly been aware of the growing political dissent within the Dutch East Indies itself. In 1939, soon after this incident, Indonesian nationalists formed GAPI (Gabungan Politik Indonesia, Indonesian Political Federation), which pushed for Indonesian autonomy from Dutch rule in return for Indonesian support against fascism. ${ }^{77}$

The story of "Malay" crews as being cut off from their homes might suggest that these men were more vulnerable to exploitation. Certainly much of the early Australian labour rhetoric which labeled them as "coolies" and "slaves", emphasized their helplessness. But we must be cautious when considering these ideas which rest on a racialized colonial notion that some Asians were inherently vulnerable, more docile,

77 M.C. Ricklefs (1981) A History of Modern Indonesia, London: Macmillan Education: 183. 
and less able to fight back. If we consider the Malay protests of the 1920s and 30s, I would argue that they demonstrated a willingness to demand justice and a clear understanding of their rights as workers that is usually overlooked by historians. By taking the longer view of Malay maritime traditions, it is possible to see the heritage that these men might have laid claim to in shaping their maritime "imagined community".

\section{Bibliography}

\section{Primary Sources}

Argus, The "The North-West Coast", 21 May 1873: 7.

_—Western Australia", 21 January 1873: 15.

_— "Dutch Mutiny", 21 February 1933: 7.

—_ "Sydney Unions Support Mutineers", 10 February 1933: 7.

__ “Javanese mutineers", 17 November 1933: 10.

Brisbane Courier "Mutiny and Murder on Board the Schooner Gift", 18 February 1873: 2.

Northern Standard, 30 August, 1 October, 8 October 1929; 19 February 1932.

—_Aroe Island Notes”, 26 February 1937.

— Letter to the editor, "The N.A.W.U. Thanked”, 23 December 1938.

__ "Indentured Laborers Obtain their wages", 14 April 1931.

— J.A. McDonald, "Indentured Labor in Darwin, White Australia Policy Flouted", 24 January 1936.

Nor'West Echo “Pearling Industry Malay Divers”, 4 April 1914.

_ "Pearling Industry", 11 July 1914.

Sun, Sydney, 1 February 1929.

Kepert to Department of Home and Territories, 25 January 1929, A1/15 28/11303, National Archives of Australia (hereafter NAA) Canberra.

Instructions Regarding Employment of Coloured Indentured Labour in the Pearling Industry, 1925, A1/15 30/880, NAA Canberra.

Crown Solicitor, Opinion, to Secretary, Attorney-General's Department, 1 March 1916, “Koepang Pearling Incidents" A1 1916/10463, NAA Canberra.

Toupein to Minister of Home Affairs, 11 January 1930, A1/15 30/880, NAA Canberra.

Customs and Excise Office, Darwin to Department of Home Affairs, 26 March 1929, A1/15 29/1132, NAA Canberra.

Memo, Sub-Collector of Customs, Darwin to Department of Home and Territories October 29, 1928, A1/15 30/880, NAA Canberra. 
Pearling Conditions, A1/15 1914/12612, NAA Canberra.

NAWU, Constitution and General Rules, Rule 6, Mitchell Library, State Library of NSW.

K. Nylander to Manager, Territory Pearling Company, 10 December 1938, F1 1938/726, NAA, Darwin.

\section{Secondary Sources}

Bain, May Albertus (1982) Full Fathom Five, Perth: Artlook Books.

Balachandran, Gopalan (2008) "Cultures of Protest in Transnational Contexts: Indian Seamen Abroad, 1886-1945”, Transforming Cultures eJournal 3 (2): 53.

Bligh, A.C.V. (1958) The Golden Quest, The roaring days of West Australian gold rushes and life in the pearling industry, Carlisle: Hesperian Press.

Cunningham, Adrian (1992) "On Borrowed Time: The Australian Pearlshelling Industry, Asian Indentured Labour and the White Australia Policy, 1946-1962”, Master of Letters thesis, Australian National University.

Dickson, Rod (2002) The Price of a Pearl, Carlisle W.A.: Hesperian Press.

Edwards, Hugh (1984) Port of Pearls, Broome's First 100 Years, Swanbourne: Hugh Edwards.

Ganter, Regina (1994) The Pearl-Shellers of Torres Strait, Melbourne: Melbourne University Press.

with contributions from Julia Martinez and Gary Lee (2006) Mixed Relations, Asian-Aboriginal Contact in North Australia, Crawley, University of Western Australian Press.

Goodall, Heather (2008) "Port Politics: Indian Seamen, Australian Unions and Indonesian Independence, 1945-4", Labour History, 94 pp 43-68.

Honniball, J.H.M. (1975) "E.H. Laurence, Stipendiary Magistrate", Early Days: Journal of the Royal Western Australian Historical Society, 7 (7): 19-24.

Ingleson, John (1986) In Search of Justice, Workers and Unions in Colonial Java, 1908-1926, Singapore: Oxford University Press.

Linebaugh, Peter \& Rediker, Marcus (2000) The Many-Headed Hydra, Sailors, Slaves, Commoners, and the Hidden History of the Revolutionary Atlantic, London: Verso.

Loney, J.K. (1994) Wrecks on the Western Australian coast: and Northern Territory, Perth: Lonestone Press.

McCarthy, Mike (1994) “Before Broome”, Great Circle 16 (2): 76-89.

Macknight, C.C. (1976) The Voyage to Marege, Macassan trepangers in northern Australia, Melbourne: Melbourne University Press.

Martínez, Julia (1999) “Questioning 'White Australia': Unionism and 'Coloured' Labour, 1911-1937”, Labour History 76: 1-19. 
Milner, Anthony (1994) The Invention of Politics in Colonial Malaya, Cambridge: Cambridge University Press.

Moor, J.H. (1837, 1968) Notices of the Indian Archipelago and Adjacent Countries, London: Frank Cass \& Co.

Moore, Ronald (1994) "The management of the Western Australian pearling industry, 1860 to the 1930s", Great Circle 16 (2): 121-138.

Philipps, Lorraine (1980) "Plenty More Little Brown Man! Pearlshelling and White Australia in Queensland 1901-1918" in E. L. Wheelwright \& K. Buckley (eds.) Essays in the Political Economy of Australian Capitalism, Vol. 4, Sydney: Australia and New Zealand Book Company.

Ricklefs, M.C. (1981) A History of Modern Indonesia, London: Macmillan Education.

Sather, Clifford (1997) The Bajau Laut: Adaptation, history, and fate in a maritime fishing society of south-eastern Sabah, New York: Oxford University Press.

Stokes, Lawrence (1977) Review of J.C.H. Blom, De muiterij op de Zeven Provincien [The Mutiny on The Seven Provinces], American Historical Review 82 (2): 377.

Sutherland, Heather (2001) "The Makassar Malays: Adaptation and Identity, c. 16601790”, Journal of Southeast Asian Studies 32(3): 397-421.

Taunton, Henry (1903) Australind: Wanderings in Western Australia and the Malay East, London: Edward Arnold.

Warren, James (1981) The Sulu Zone, 1768-1898, Dynamics of External Trade, Slavery, and Ethnicity in the Transformation of a Southeast Asian Maritime State, Singapore: Singapore University Press. 